\title{
A Solution to the Fingering Problem of Brahms Cellos Sonata No. 1 Opus 38 and Shostakovich Cello Sonata Opus 40
}

\author{
Asep Hidayat Wirayudha ${ }^{1}$
}

Jurusan Musik, Fakultas Seni Pertunjukan, Institut Seni Indonesia Yogyakarta

\begin{abstract}
The flexibility of fingers is one main factor of responsibility on their spread ability. Considering the cello playing, the spread ability of cellists' fingers is very important since it has a direct correlation to their ability to play the octave interval. The short-fingers cellists would find difficulties to play the octave intervals at the first, second, third, and fourth position. Nevertheless, short-fingers are not dead-end for cellist. The spread ability of finger, up to some extent, might be increasing through practices and exercises. It is with this spirit that the author proposes some stratagems, which may be used to increase the spread ability of a cellist's fingers in this section - using the octave interval problems as a case of pint. The discussion on the types and styles of problem show that even though the octave intervals in Brahms cellos sonata No. 1 opus 38 and Shostakovich cello sonata opus 40 are different in details, but fundamentally they are similar: the problems come from the difficulty of the first and the fourth fingers to reach the proper note when the size and length of the fingers are limited.
\end{abstract}

Keywords: Brahms Sonata cello No.1 opus 38, Shostakovich, octave, interval

\begin{abstract}
ABSTRAK
Solusi dari Permasalahan Fingering dalam Brahms Cellos Sonata No.1 Opus 38 dan Shostakovich Cello Sonata Opus 40. Kemampuan penyebaran jari pemain cello sangat penting karena memiliki korelasi langsung dengan kemampuan mereka untuk bermain interval oktaf. Jari-jari pendek pemain cello akan menemukan kesulitan untuk bermain interval-interval oktaf di posisi pertama, kedua, ketiga, dan keempat. Namun demikian, kemampuan penyebaran jari, bisa ditingkatkan melalui praktik dan latihan. Hal tersebut menggugah penulis untuk mengusulkan beberapa siasat baru mengenai kemampuan teknis memainkan interval dan oktav dan persoalan jarak interval dalam konteks Sonata yang dapat digunakan untuk meningkatkan kemampuan penyebaran jari seorang pemain cello. Meskipun interval oktaf di Brahms cello sonata No 1 opus 38 dan Shostakovich cello sonata opus 40 berbeda, tetapi pada dasarnya keduanya sama: masalah datang ketika kesulitan terjadi pada jari pertama dan keempat untuk mencapai nada yang tepat ketika ukuran dan panjang jari-jari terbatas.
\end{abstract}

Kata kunci: Brahms Sonata cello No.1 Opus 38, Shostakovich, oktav, interval

\section{Introduction}

The principles of neck-position fingerings on cello have been evolved since the cellist of eighteenth-century extended their range beyond the first position. The principles have greatly improved the skill of cellists to perform musical composition. However, by its nature, fingering is a personal matter. What is regard as suitable principles or rules to one hand will not always suit another. Therefore, one cannot lay down any strict rules of fingerings although there are certain general principles that can be followed. Among many factors determining the suitability of any principles of cello fingering, the size of a cellist's fingers is one factor that seemingly out of notice. The available cello fingering methods is generally suitable for a cellist having relatively long fingers. Those having relatively short fingers may find many difficulties to apply the principles.

Alamat korespondensi: Jurusan Musik, ISI Yogyakarta. Jln. Parangtritis km 6,5 Sewon, Bantul, Yogyakarta. Email: dhenbullex@hotmail.com 
The aforementioned condition, which may cause serious problems on the performance of short-fingers cellists, warrants new methods or approaches to improve their skills. It is in this context the author processes any modifications of the available octave and far interval etudes in order to improve the performance of cellist. The Brahms cello sonata cello No. 1 op. 38 and the Shostakovich cello sonata op. 40 are used as cases of point.

Within the context of Brahms Sonata cello No. 1 opus 38 and the Shostakovich cello sonata opus 40 , the author divides the problem into two types. They are: (1) octave interval and (2) far interval problem. In order to make the problems become clear, it is imperative to define the octave and far intervals first. Octave intervals are intervals where cellists have to play two musical notes from the necessity to place the fingers in two farseparated positions. Such a necessity may cause the short-finger cellists feel pain and discomfort. Some cellists, moreover, may not reach the proper position at all.

Far intervals are intervals where cellists have to move from one note to another that it is at least one octave higher or lower in a short time. Far intervals, especially those required cellists to change position, are classic problem for any cellists virtually. The following passages describe the octave interval in the Brahms cello sonata No. 1 opus 38 and Shostakovich cello sonata opus 40 , which according to the author's assessments may become serious problems to any short-fingers cellists. Therefore, those intervals were selected from the point of view of the relatively short-finger cellists. It was followed then by the expositions of far intervals, from the same sonatas that might become problem for many cellists.

\section{Octave Interval Problems}

There are seven octave intervals of Brahms cellos sonata No.1 opus 38 that present special difficulties for the short-fingers cellists. The first difficulty is located at the first movement, measure 5 (figure 1).
The difficulty to perform this interval comes from the fact that it requires the first and the fourth fingering to spread on two relatively far-separated notes, especially on the lower note. The second difficulty is located at the first movement measure 130 (figure 2).

This interval became difficult to be performed since it compels two far-separated notes-the $B_{b}$ and $F$ to be played at the same time in the context of fortissimo. The similar difficulties are found at the third movement, measure 13, 35, and 45 (see figure 3 to 5).

The sixth and relatively difficult octave interval is situated at the second movement, measure 49 (figure 6).

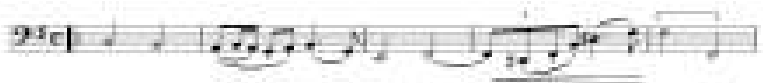

Figure 1. Octave interval at the first movement, measure 5 of the Brahms cello sonata No.1, opus 38.

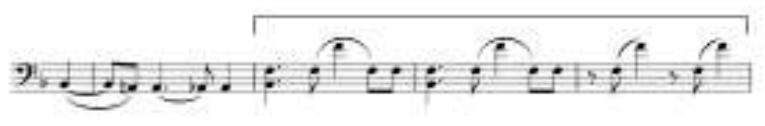

Figure 2. Octave interval at the first movement, measure 130 of the Brahms cello sonata No.1, opus 38 .

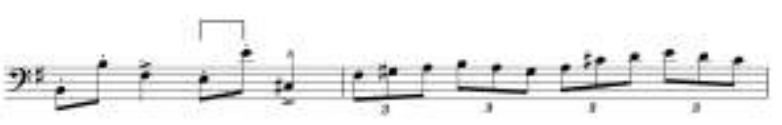

Figure 3. Octave interval at the third movement, measure 13 of the Brahms cello sonata No.1, opus 38.

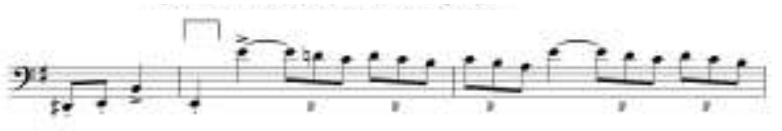

Figure 4. Octave interval at the third movement, measure 35 of the Brahms cello sonata No.1, opus 38 .

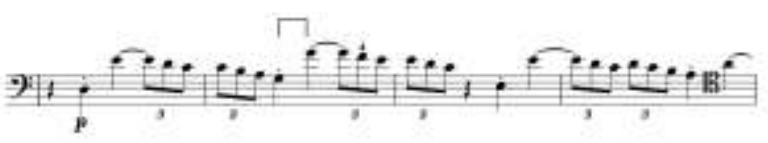

Figure 5. Octave interval at the third movement, measure 45 of the Brahms cello sonata No.1, opus 38.

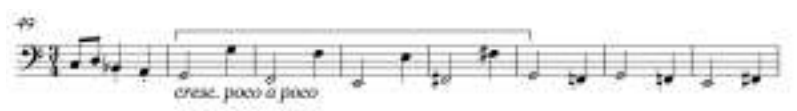

Figure 6. Octave interval at the second movement, measure 49 of the Brahms cello sonata No.1, opus 38.

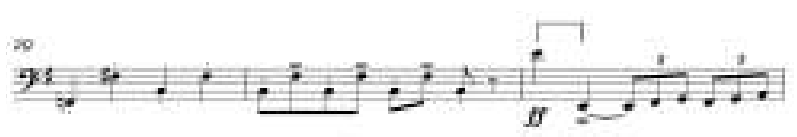

Figure 7. Octave interval at the second movement, measure 31 of the Brahms cello sonata No.1, opus 38. 
The problem on this octave interval occurs from the difficulty to use the first and the fourth finger in order to exploit optimally lower notes in the contact of fortissimo. The seventh point of difficulty is found at the third movement, measure 31 (figure 7).

The difficulty to play the aforementioned interval comes from the necessity to play the nearscroll interval atfast tempo and the dynamics of fortissimo. In the Shostakovich cello sonata Opus 40 , the author finds four octave intervals that may become problem to the short-fingers cellists. The first interval is located at the first movement, measure 71 (figure 8).

The difficulty to perform this interval occurs from the necessity to move the lower $F \neq$ to upper $F \neq$ at short time under the legatissimo expressivo. Other point of difficulty is located at the first movement, measure 149 (figure 9). This interval in figure 9 becomes difficult to be performed since it requires two far-separated notes-the lower $E_{b}$ and upper $E_{b}$ to be played in the context of fortissimo. The similar difficulty is found at the first movement, measure 130, in the Brahms cello sonata No.1 Opus 38, (see figure 2). The fourth point is situated at the third movement, measure 74 (see figure 11). The interval above may become a problem since it necessitates the cellists to play the interval in the dynamics of piano phrase. Such a necessity may cause the phrase unclear.

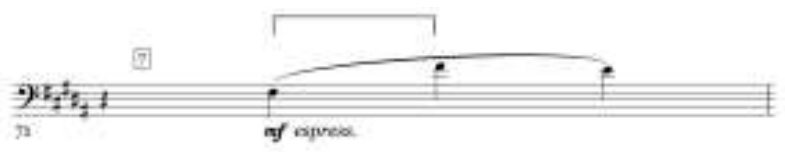

Figure 8. Octave interval at the first movement, measure 71 of the Shostakovich cello sonata opus 40.

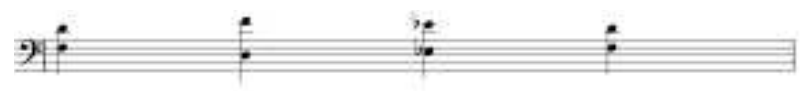

Figure 9. Octave interval at the first movement, measure 149 of the Shostakovich cello sonata opus 40.

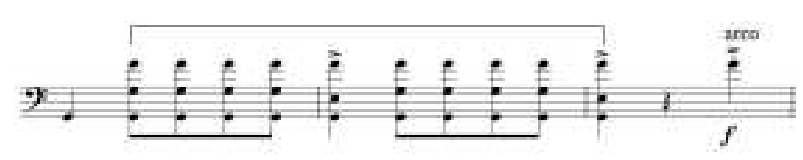

Figure 10. Octave interval at the second movement, measure 61-63 of the Shostakovich cello sonata opus 40.

\section{The Far Interval Problem}

There are four far intervals of the Brahms cello sonata No. 1 Opus 38. They are located at the first movement, measure 26-29 and 110-112 and at the third movement, measure 115 and 166-169. The difficulty to play the first point (figure 12) occurs from the fact that, firstly (at measure 26), it compels the cellist to move from the first to the fifth position and, secondly (at measure 28), from the fourth to the sixth position.

The second point of difficulty (figure 13) necessitates the cellist to move, in a short time; from the $D$ bin the fourth beat of the measure 110 to the same note situated one octave higher. Moreover, such a movement is followed by the shifting, also in a short time, from the lower $F$ of measure 112 to the upper $F$ that is two-octave higher.

The far interval at the third movement, measure 115 (figure 14) presents the optimal problem of the sound quality since it necessitates the cellists making a relatively far shift.

The last far intervals that are difficult to be performed, located at the third movement, measure 166-169 (figure 15). They compel the cellist to move from the note $B$ to the note $C \neq$ that is threeoctave higher. This is difficult to be played (it is the farthest interval in the Brahms cellos sonata No. 1 opus 38). Moreover, this may become a problem since it is located at the third movement. At that moment, the fingers may have already exhausted from the previous movement. According to the author's assessments, there are two far interval problems in the Shostakovich cello sonata Opus 40. They are located at the first movement, measure 33 and 42.

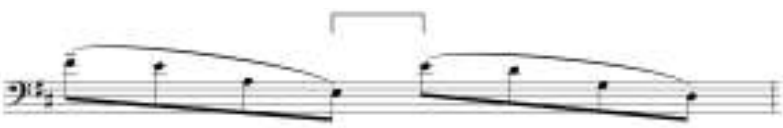

Figure 11. Octave interval at the third movement, measure 74 of the Shostakovich cello sonata opus 40 .

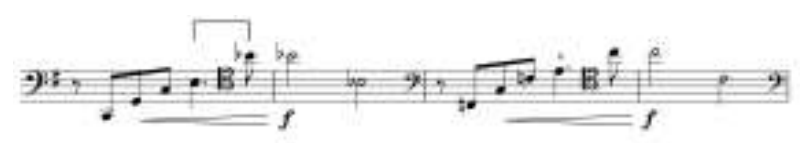

Figure 12. Far interval at the first movement, measure 26-29 of the Brahms cello sonata No. 1, opus 38. 


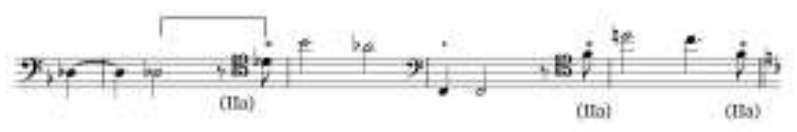

Figure 13. Far interval at the first movement, measure 110-112 of the Brahms cello sonata No. 1, opus 38.

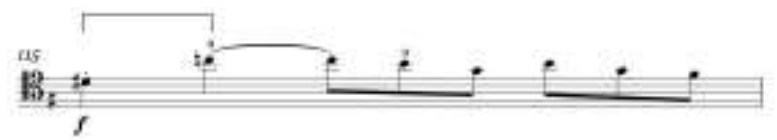

Figure 14. Far interval at the third movement, measure 115 of the Brahms cello sonata No. 1, opus 38 .

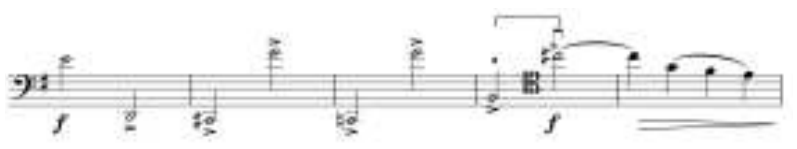

Figure 15. Far interval at the third movement, measure 166169 of the Brahms cello sonata No. 1, opus 38.

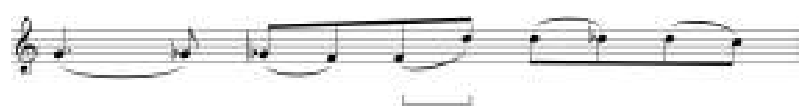

Figure 16. Far interval at the first movement, measure 33 of the Shostakovich cello sonata opus 40.

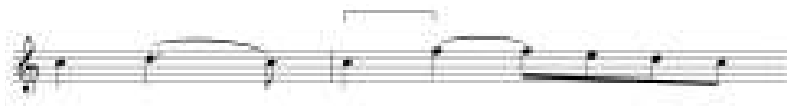

Figure 17. Far interval at the first movement, measure 42 of the Shostakovich cello sonata opus 40.

The first difficulty (figure 16) presents a classic intonation problem. It compels the cellists to move from $\mathrm{F}$ in the fourth position to $\mathrm{D}$ in the fifth position.

The second point of difficulty (figure 17) presents a specific difficulty to short-finger cellists since they would find a constrain in order to spread their fingers properly on the note $\mathrm{C}$ and $\mathrm{F}$ in the seventh position.

\section{Solution to the Octave Interval Problem}

Fingers, by their nature, are flexible since they are built mainly by soft tissues and muscles. The flexibility of fingers is one main factor of responsibility on their spread ability. Considering the cello playing, the spread ability of cellists' fingers is very important since it has a direct correlation to their ability to play the octave interval. The short- fingers cellists would find difficulties to play the octave intervals at the first, second, third, and fourth position. Nevertheless, short-fingers are not dead-end for cellist. This is according to the article Recital Vol. No.14. 1, June 2013: page 45 Jaipongan: Genre Tari Generasi Ketigadalam Perkembangan Seni Pertunjukan Tari Sunda By Lalan Ramlan "The Main principle in the work is Creative courage". There is a similarity in addressing the problem in context of creativity, the spreadability of finger, up to some extent, might be increasing through practices and exercises. It is with this spirit the author proposes some stratagems, which may be used to increase the spread ability of a cellist's fingers in this section - using the octave interval problems as a case of pint. The discussion on the types and styles of problem showed that even though the octave intervals in Brahms cellos sonata No. 1 opus 38 and Shostakovich cello sonata opus 40 were different in details, but fundamentally they were similar: the problems came from the difficulty of the first and the fourth fingers to reach the proper note when the size and length of the fingers were limited. The difficulty may be solved through the exercises depicted in figure 18. The author proposes six of exercises that may be used to increase the spreadability of short-fingers cellist. The exercises are directed to the $G$ string. All of the exercises, however, may be applied and modified to other strings, fingers, and rhythms according to the personal need.

\section{Solution to the Far Interval Problem}

1. Solution to the Problem at the First Movement, Measure 26-29 of the Brahms cellos sonata No. 1 opus 38
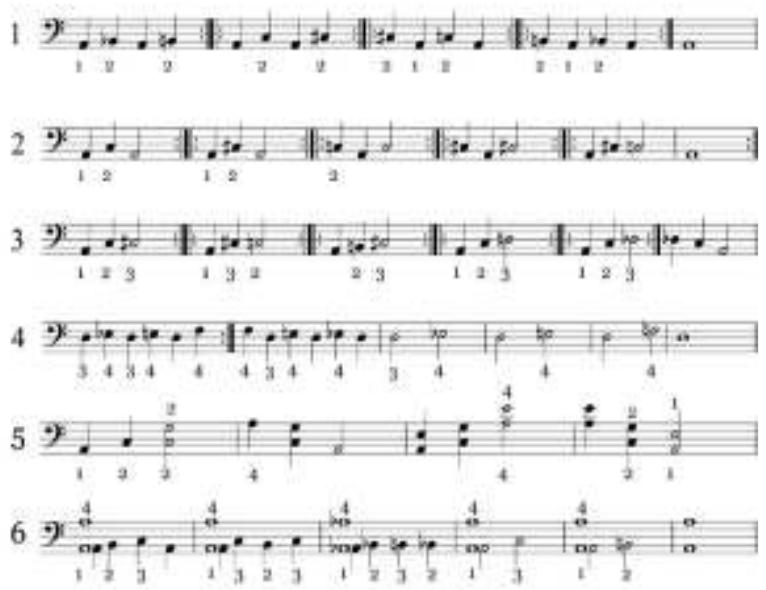

Figure 18. Six variations of exercises to increase the spreadability of short-fingers celists 


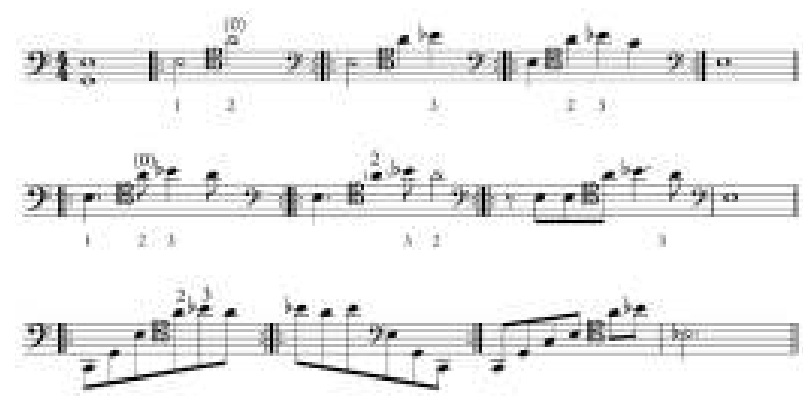

Figure 19. Three-steps exercise to practice the shifting from the $E$ to $B b$

The fingers shifting always become problems. In the case of the movement 1 , measure 26-29 of the Brahms cellos sonata No. 1 opus 38 (figure 12), the requirement of fingers to shift from $E$ (first position) to $B_{b}$ (fifth position) may result the discordant tone of the $B b$. To solve this problem, the author proposed the following exercise (figure 19). It consisted of the playing of the $E$ and $G$ (open string) in slow tempo, to make sure that the intonation was concordant, followed by the shifting from the $E$ to $A$ (open string) in slow tempo and glissando using the second finger. Such a position would make the $\mathrm{B}_{\mathrm{b}}$ could be reached easily using the third finger. The repetition of this exercise using the $E-A-B b, B b-A-E$, and their variations would give a better result.

2. Solution to the Problem at the First Movement, Measure 110-112 of the Brahms cellos sonata No. 1 opus 38

To solve the problem at the case of the movement 1 , measure 110 of the Brahms cellos sonata No.1 Opus 38, (see figure 13), the author proposed the following exercise (figure 20). Firstly, play of the lower $D_{b}$, and approach the fifth position, its role is changed by the second fingers. The pressing of the $D$ string (flageolet) by the third finger should be used as an intonation controller.

The solution to the problem at the movement 1 , measure 112 of the Brahms cellos sonata No.1 Opus 38, (figure 13) is basically the same as those for the measure 110 . There are two alternatives to shift from the lower $F$ to the upper $\mathrm{F}$ notes. The first alternative is pressing the lower $\mathrm{F}$ note that is located at $A$ string using the second finger (four position). Consequently, the $D$ note that should be played at the first beat of the measure 111 is located relatively far from the $F$ note and may not be reached properly. The possibility to use this alternative successfully would be increased through the following exercise (figure 21). Firstly, play the $F$ note using the second finger in the slow tempo. Secondly, shift to the fifth position. By the end of this motion, the $D$ major scale is established which, in turn, making the $D$ note reachable.

The second alternative (figure 22) is started by pressing the lower $F$ note that is located at the $D$ string using the first finger (fifth position). The pressing of the $D$ string (flageolet) by the thumb should be used as an intonation controller. In such a configuration, the upper $F$ note may be then reached by the second finger at the $A$ string (fifth position).

From the aforementioned explanation, it is clear that two alternatives are similar to the main difference in the string used to define the lower $F$ notes.

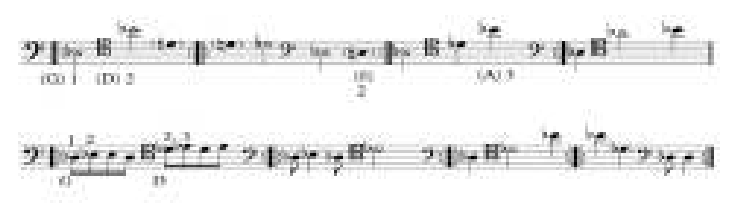

Figure 20. Two-steps exercise to practice the shifting from the lower $D_{b}$ to the upper $D_{b}$

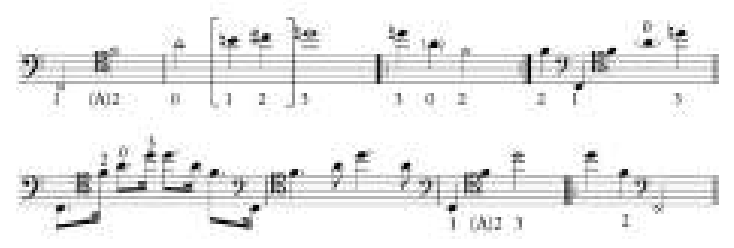

Figure 21. The first alternative of the two-steps exercise to practice the shifting from the lower $F$ to the upper $F$

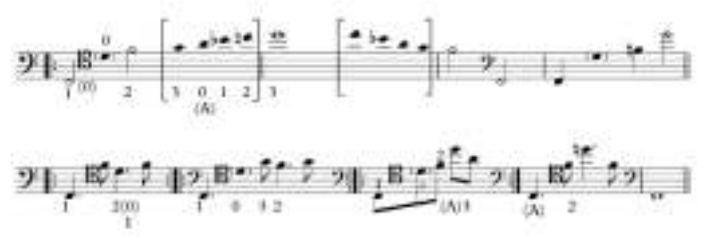

Figure 22. The second alternative of the two-steps exercise to practice the shifting from lower $F$ to the upper $F$ 

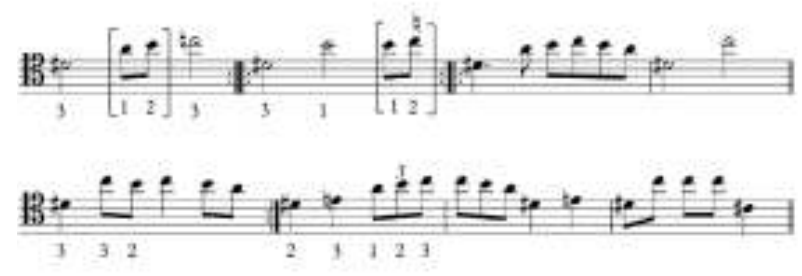

Figure 23. Two-steps exercise to practice the shifting from $D \#$ to $C$

3. Solution to the Problem at the Third Movement, Measure 115 of the Brahms cellos sonata No. 1 opus 38

To solve the problem at the third movement, measure 115 of the Brahms cellos sonata No. 1 opus 38, (see figure 14), the author proposed the following exercise (figure 23). Firstly, press the $D \neq$ note using the third finger. Secondly, shift to find and reach easily using the third finger. Pressing the $A$ string (flageolet), before shifting from $D \neq$ to $C$, may be done controlling the intonation.

4. Solution to the Problem at the Third Movement, Measure 169 of the Brahms cellos sonata No. 1 opus 38

To solve the problem at the third movement, measure 169 of the Brahms cello sonata No. 1 opus 38, (see figure 15), the author proposed the following exercise (figure 24). In essence, the exercise is similar to those for the third movement, measure 115 of the Brahms cello sonata No.1 opus 38 as explained above.

Firstly, press the $B$ note using the third finger. Secondly, shift to find and press the $A$ note using the thumb in glissando. By controlling the flageolet, to make the fifth position, then the $C \neq$ would be reached easily.
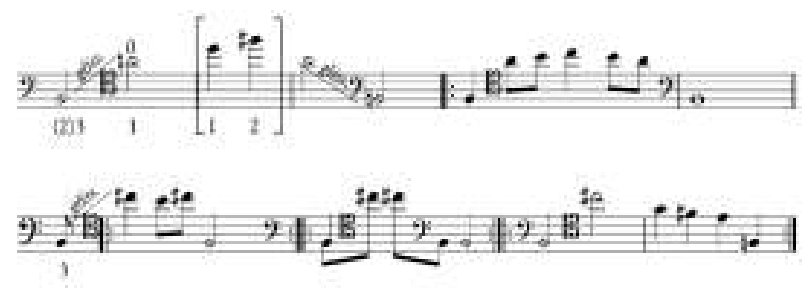

Figure 24. Two-steps exercise to practice the shifting from the lower $B$ to the upper $C \#$
5. Solution to the Problem at the First Movement, Measure 33 of the Shostakkovich Cellos sonata Opus_40

One alternative solution for the problem of the first movement, measure 33 of the Shostakovich cello sonata opus 40 (see figure 16) is depicted in figure 25.

Firstly, play the $F$ note in the fourth position using the second finger. Secondly, shift to the $D$ note in the fifth position using the third finger. Control the last note using the open string $D$. The next exercise is to shift from the $F-G b$ to $D$ notes, and conversely. Repetition of the aforementioned exercise to make the stratagem second mature and, in turn, make the shifting from the $\mathrm{F}$ to $\mathrm{C}$ notes could be done directly.

6. Solution to the Problem at the First Movement, Measure 42 of the Shostakkovich Cellos sonata Opus 40

The following exercise (figure 26) might be used to solve the problem of the first movement, measure 42 of the Shostakovich cello sonata opus 40 (see figure 17). Firstly, play the $C-E-F$ notes using the first, second, and third fingers, respectively. This exercise should be done repeatedly and the $C$ note should be controlled using the open string $C$. All notes might be varied as depicted in figure 26. To minimize the strain during this exercise, it should be stopped when the cellists feel pain in any parts of the body.

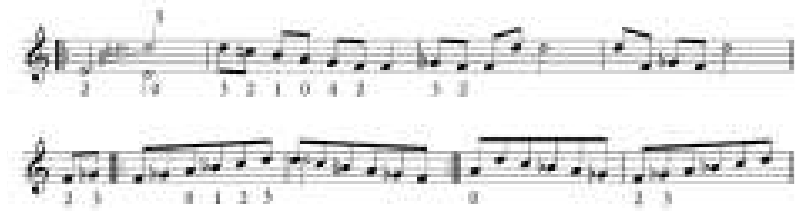

Figure 25. Two-steps exercise to practice the shifting from the lower $F$ to the upper $C$

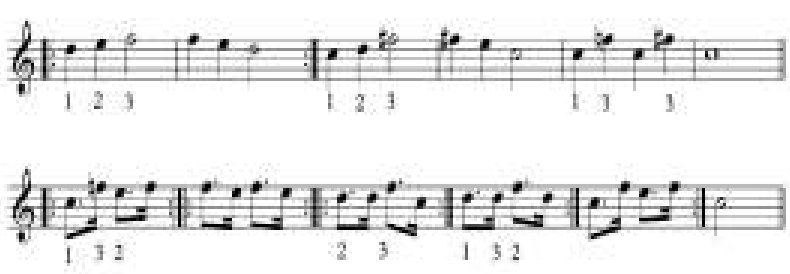

Figure 26. The exercise to practice the $C-E-F$ shiftings 


\section{Conclusions}

The fingering problems may pose special difficulties to any cellists. According to the author's assessment, there are two problems that warrant special attentions of the cellists. They are the octave and far intervals. The octave intervals may cause serious problems on the performance of shortfingers cellists. The problem occurs mainly from the limitation of the spreadability of the shortfinger cellists. Nevertheless, the author believes that the inherent short fingers are not dead- end. The proposed simple stratagems explored in details in this thesis show that there are many ways to compensate such limitation. More importantly, the author believes that there are still many stratagems to be explored. The far intervals, that become classic problem for any cellists, may also be mastered through some simple stratagems. As we can see many far intervals that may previously be seen as difficult problems, they may not be difficult in them self. The problem may actually come from our limitation to find many side tracks. Such side-tracks, that may not follow the traditional principles or rules of fingering, should not be regarded as a kind of desertion. They should be regarded as products of creative minds, instead. The discussions in this thesis is limited to some octave and far intervals in the Brahms sonata No. 1 opus 38 and the Shostakovich cellos sonata opus 40 that may be regarded as difficult parts of the sonatas. However, the author believes that the proposed stratagems for the intervals, especially those for the octave intervals, may be used as alternatives to play other cellos compositions, probably through some modifications, depending on the composition. It is merely not a matter of composition, but it is a matter of imagination and creativity.

\section{Bibliography}

Clarke, Eric. 2010. Music and Mind in Everyday Life. Oxford: Oxford University Press.

Eisenberg, M. 1957. Cello Playing Today. London: Lavender Publication LTD.

G, Verlag Henle. 1977. Brahms Sonata Klavier und Violoncello No.1 op, 38 Munchen.

Pleasant, Hendry. 1990. Music Criticsms. London: Sage.

Stephen Collin, 2004. Teach Your Self-Classical Music. England: Cox \&Wayman Ltd.

Stowell, Robin. 1999. Enjoyment of The Cello. United Kingdom: Cambride University Press.

Stowell, Robin. 2000. String Quartet. London: Sage.

Stephen Collin. 2004. Teach Your Self-Classical Music. England: Cox \& Wayman Ltd.

Stowell, Robin. 1999. Enjoyment of The Cello. United Kingdom: Cambride University Press.

Stowell, Robin. 2000. String Quartet. London: Sage.

Cograss, Ulla. 2001. For The Love of Music. New York: Mcmillan Ltd.

Pleasant, Hendry. 1990. Music Criticsms. London: Sage.

Ramlan Lalan. 2013. “Jaipongan: Genre Tari Generasi Ketiga dalam Perkembangan Seni Pertunjukan Tari Sunda" in Resital Journal of Performing Arts Vol. 14 No. 1, Juni, p. 45.

Welden, V. 1999. The Cambride Companion To The Cello. Cambridge: Cambride University Press

Zen-On. 2000. Shostakovich Sonata Cello and Piano opus 40. Tokyo. 